(10) P.Jaegele, G.Missoni and P.Dhez : Phys. Rev. Letters, 18(1967), 887.

(11) P. Jaegele, F. Combet Farnoux, P. Dhez, M. Cremonese and G.Onori : Phys. Letters, $26 \mathrm{~A}$ (1968) , 364.

(12) R.Haensel, C.Kunz, T.Sasaki and B.Sonntag : Appl.Optics, 7 (1968) , 301.

(13) S.T.Manson and J.W.Cooper : Phys. Rev., 165 (1968), 126.

(14) A.R.P.Rau and U.Fano: Phys. Rev., 167 (1968), 7.

(15) B.L.Henke, R. White and B.Lundberg: J.Appl. Phys., 28(1957), 98

(16) A.J.Bearden : J.Appl.Phys., $37(1966), 1681$.

(17) E.Kohlhaas und F.Scheiding : Vth Internat.Cong. on X-Ray Optics and Microanalysis, Tübingen 1968,
Springer-Verlag, Berlin, (1969), 193.

(18) 渡讱 融, 大平五郎：金属学会誌，37(1973)，697。

(19) R.D.Dewey, R.S.Mapes and T.W.Reynolds : Handbook of X-Ray and Microprobe Data, Pergamon Press, London, (1969), 3.

(20) 正藤和男, 保木栄次：金属学会誌，37(1973)，487.

(21) J.B.Bearden : Rev.Mod.Phys., 39(1967) , 78.

(22) J.B.Bearden and A.F.Burr : Rev. Mod.Phys., 39 (1967), 125.

(23) S.J.B.Reed : Brit.J.Appl.Phys., 16(1965), 913.

(24) 橋口隆吉, 近角聡信: 薄膜·表面現象，材料科学講 座 6 , 朝會書店, (1969), 70 .

(25) U.Fano and J.W.Cooper : Rev. Mod. Phys., 40 (1968), 441.

（26）会田筱，住川敬：金属学会会報，11(1972)， 781 .

\title{
ニオブ 水素化物の内部摩擦
}

\section{天 野 宗 幸* 佐々木 靖 男*}

Muneyuki Amano and Yasuo Sasaki : Internal Friction in Niobium Hydride. The internal friction in $\mathrm{NbH}_{0.43}, \mathrm{NbH}_{0.75}$ and $\mathrm{NbH}_{0.84}$ was measured in a temperature range from $-170^{\circ} \mathrm{C}$ to $220^{\circ} \mathrm{C}$. The observed internal friction was compared with the results of differential thermal analyses, electrical resistance measurements, electron diffraction and transmission electron microscopy.

Sharp damping peaks were observed at the temperature of the eutectoid transformation for $\mathrm{NbH}_{0.43}$ and the temperatures of the $\beta-\alpha^{\prime}$ transformation for $\mathrm{NbH}_{0.75}$ and $\mathrm{NbH}_{0.84}$. Each alloy also showed a peak at the temperature of phase transformation associated with the change in ordering of hydrogen in the hydride phase.

A peak which is not associated with phase transformation was found below room temperature. This peak shifted to lower temperatures with increasing hydrogen content in the hydride phase. And, it showed a frequency dependence and its activation energy was about $30 \mathrm{kcal} / \mathrm{mol}$. High background damping was observed in the temperature range from this peak to the temperature of the eutectoid or the $\beta-\alpha^{\prime}$ transformation, and it showed a large amplitude dependence. Domain boundaries were frequently observed in the hydride phase and were very mobile under thermal stress caused by electron irradiation.

It is concluded that the peak which is not associated with the phase transformation is caused by a cooperative motion of hydrogen atoms at the domain boundaries in the hydride phase and the high background damping is attributed to the irreversible movements of the domain boundaries.

(Received May 14, 1974)

\section{I. 緒言}

ニオブは Va 族の金属であり，水素と発熱的に反忘し， 多量の水素を吸収する(1). Fig.1 K Nb-H 系状態図(2)を示 す.ニオブの機栈的乩よび物理的性質は水素を吸収するこ とにより著しく変化する。ニオブ中の水素の挙動を明らか にするための有効な手段の一つとして，内部摩擦湘定があ る。ニオブ中の水素汇関連した内部摩擦として報告されて いるものは次の上らに分類される。

(1) 固溶水素のS Snoek 効果 ${ }^{(3)}$ (短範困挔散) 贴よび Gorsky 効策 ${ }^{(4)(5)}$ (長範囲拡散)
(2) 固溶水素之転位との相互作用 ${ }^{(6) \sim(8)}$

(3) 水素化物 ( $\beta$ 相)の析出 ${ }^{(9)(10)}$

(4) 共析変態(9)

(5) $\beta-\alpha^{\prime}$ 変態(11)

（6）水素化物中の水素の規則配列の变化をともなら相変 態(11)

（7）水素化物中の水素の外力以上る再配列(11)

上記の (1) がら (4) 飞起因する内部摩擦に関しては，水 素量が 10 at\% 以下の低水素ニオブ合金について多くの報

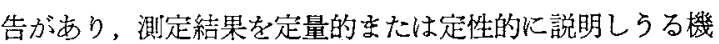
構が提案されている.しかし，水素化物の単相からなって

* 金属材料技術研究所 (National Research Institute for Metals, Tokyo) 


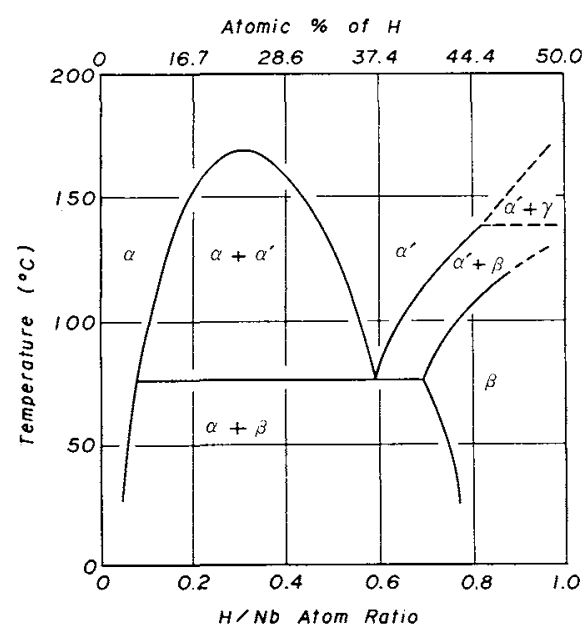

Fig. I Phase diagram of the $\mathrm{Nb}-\mathrm{H}$ system. (from Walter and Chandler ${ }^{(2)}$ )

いる合金あるいは水素化物を多量に含有する高水素ニオブ 合金の内部摩擦については不明の点が多い. Ta-H 系につ いてはKofstad ら ${ }^{(2)}$ が，またV-H系については Butera $ら^{(13)}$ が水素化物相比関連した内部摩擦を測定し，中珄子 回折 ${ }^{(14)}$ ，電気抵抗測定 ${ }^{(14)}$ 特よび熱分析 ${ }^{(15)}$ の結果とあわせ て報告している，著者ら(11) 性，窒温に执いて水素化物の 単相からなっている $\mathrm{NbH}_{0.75}$ の内部摩擦を測定し，その結 果を電気抵抗測定，示差熱分析㧠よび透過電顕観察の結果 と比較検討することにより, 前述の (5)から（7）火基づく 内部摩擦を見出した。

ニオブ水素化物は，Fig.1に示されるように広い組成域 を有している，したがって水素化物中の水素濃度が变化す れば，その内部摩擦孔変化することが予湘される。すなわ ち，水素化物中の水素濃度が $\mathrm{NbH}$ の化学当量論的組成加 ら減少すると，水素の空孔の量が増大し，空孔の配列の変 化拈よび水素の易動度の変化が期待される．水素化物中の 水素濃度の变化にともなら内部摩擦の変化に関しては, 今 までほとんど研究されていない。

本研究に执いては，室温で水素化物相のみからなってい る $\mathrm{NbH}_{0.84}$ および $\mathrm{NbH}_{0.75}$ ならびに多量の水素化物相を含 有している $\mathrm{NbH}_{0.43}$ にみられる内部摩擦の機構を明らかに することを目的とした，内部摩擦测定結果の考察の助子と して，示差熱分析，電気抵抗測定，透過電子顕微鏡観察打 よび電子回折をあすせて行なった。

\section{II. 実 験 方 法}

\section{1. 試料作製}

実験に用いたニオブ素材は Kawecki Berylco 社製の直䍐 $1 \mathrm{~mm}$ の線と， $0.15 \mathrm{~mm}$ 厚の板で，純度は $99.9 \%$ であっ た.これらの素材を $5 \times 10^{-6}$ Torr の真空中 $1200^{\circ} \mathrm{C} て ゙ ~ 1 \mathrm{hr}$ 焼鈍した。焼鈍線の内部摩擦值を，Powers とDoyle ${ }^{(16)} に$
よって報告されているデーターと比較することにより，㷬 鈍線中の酸素は的 $110 \mathrm{ppm}$, 窒素と炭素は合計で約 $60 \mathrm{ppm}$ であると概算された。

ニオブへの水素添加は，ジルコニウム水素化物の熱分解 に上って得られる高純度水素ガスの一定量と二才ブ烓銛線 材を $700^{\circ} \mathrm{C}$ で反応させた後，炉冷することによってなさ れた。本法によって $\mathrm{NbH}_{0.84}, \mathrm{NbH}_{0.75}$ 梠よび $\mathrm{NbH}_{0.43}$ を 作製した。

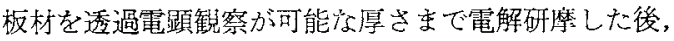
$\mathrm{NbH}_{0.84}$ の粉末ととをに透明不英管中に真空封入し， 700 ${ }^{\circ} \mathrm{C} に 1 \mathrm{hr}$ 保持後炸冷した。粉来と薄膜との重量比は約 1000 対 1 であり，薄膜は污染を避けるために粉末中に埋 められた。本法によって核滦 $\mathrm{NbH}_{0.84}$ の透過電显用薄膜を 作製した。

作製された試料中の水素濃度は真空溶融法によって分析 された。

\section{2. 実験方法}

内部摩擦測定，電気抵抗測定怙よび示差熱分析には線状 試料を用いた。内部摩摖の測定は逆吊りの自由振偅法によ って行なった，測定は主として昇温侍に行ない，昇温速度 は約 $0.5^{\circ} \mathrm{C} / \mathrm{min}$ であった。測定温度範囲け $-170^{\circ} \mathrm{C} か ら$ $220^{\circ} \mathrm{C}$ であった，電気抵抗湘定は 4 端子法で，界温乱び 冷却時比行ない, 平均昇温就よび泠却速度は $0.2^{\circ} \mathrm{C} / \mathrm{min}$ であった．電気抵抗の測定温度範国は $-196^{\circ} \mathrm{C}$ から $140^{\circ} \mathrm{C}$ であった，示美熱分析は主として昇温洔に行ない，昇温速 度は $1^{\circ} \mathrm{C} / \mathrm{min}$ であった。示差熱分析の標準試料として, 純ニオブ線を用いた，气の湘定温度範围は $-196^{\circ} \mathrm{C}$ から $150^{\circ} \mathrm{C}$ であった。 上述の測定はすべてへリウム雲囲気中で 行なった。

透過電影観察於上び電子回折は， $-150^{\circ} \mathrm{C} か ら 120^{\circ} \mathrm{C}$ K 至る温度領域において行なった。缹温以下における観察に は島津 SMH-5 B 電子顕微鏡を，また室温以上における観 察には日本電子 JEM-150を，そ机ぞれ加速電压 $500 \mathrm{kV}$ 和よび $150 \mathrm{kV}$ で使用した。

\section{III. 実 験 結 果}

$\mathrm{NbH}_{0.43}, \mathrm{NbH}_{0.75}$ および $\mathrm{NbH}_{0.84}$ の们部摩擦測定結思を Fig.2 に示寸。本㘠から明らかなように 3 種類の合金の内 部摩擦に多くの類似点が珰められる。各全金にみられた内 部摩擦のピークと相変態との対芯を知るための, 示差熱分 析括よび電気抵抗測定の絬梁を Fig.3 および Fig.4 に示 す. Fig.2, Fig.3 および Fig.4 を比較対照すると以下のこ とが明らかになる。

$\mathrm{NbH}_{0.43}$ の内部摩擦佃線において, $-70,-31,88$ およ び $165^{\circ} \mathrm{C}$ にピークが琹められる。 それらのピーク温度の 5口示差熱分析および電気抵抗呦線の変化に対応寸るもの は， -70 拈よび $88^{\circ} \mathrm{C}$ ピークであり，これらのピークは相 変態基らくくものと考学られる。 $\mathrm{NbH}_{0.75}$ に扔いても, 同 


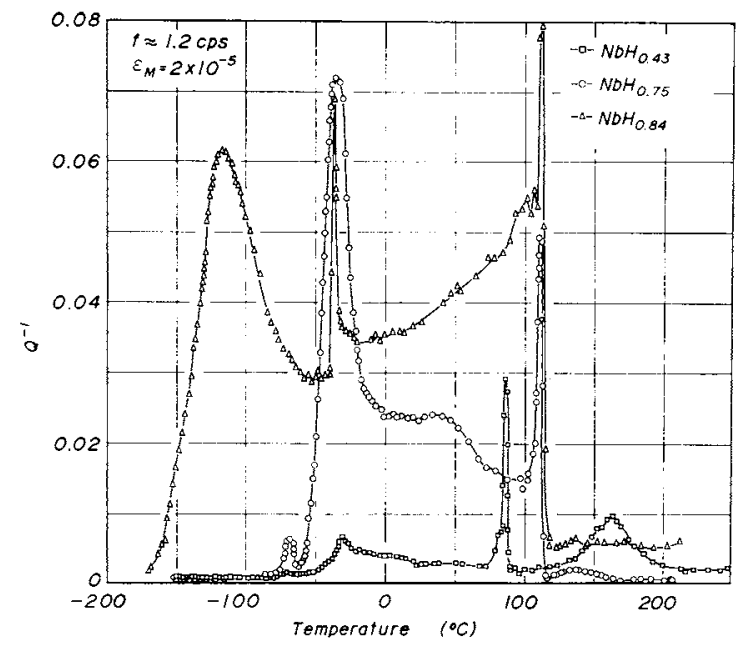

Fig.2 Internal friction in $\mathrm{NbH}_{0.43}, \mathrm{NbH}_{0.75}$ and $\mathrm{NbH}_{0.84}$.

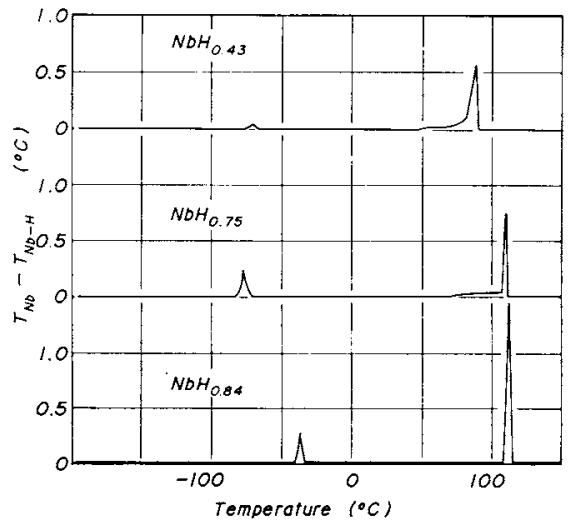

Fig.3 Differential heating curves of $\mathrm{NbH}_{0.43}$, $\mathrm{NbH}_{\mathbf{0 . 7 5}}$ and $\mathrm{NbH}_{\mathbf{0 . 8 4}}$.

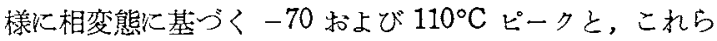
以外に -35 および $135^{\circ} \mathrm{C}$ にピークが浔められる。すた $\mathrm{NbH}_{0.84}$ においては，相変態に基つく -38 およ゙ $112^{\circ} \mathrm{C}$

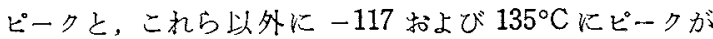
瑟的られる。

各合金において，相変態に基づく二つのピークのらら高 温にみられるピークを Fig.1 の状態図と対応してみると， $\mathrm{NbH}_{0.43}$ の $88^{\circ} \mathrm{C}$ ピークは共析変熊, $\mathrm{NbH}_{0.75}$ の $110^{\circ} \mathrm{C}$ ピ 一クおよび $\mathrm{NbH}_{0.84}$ の $112^{\circ} \mathrm{C}$ ピークは $\beta$ - $\alpha^{\prime}$ 変態に基づく ものであることが推察できる。これらのピークを本論文で は相変態高温ピークと総称する。な怙相変態に基づくピー クのらち低温側でみららるものを，本論文では相変態低温 ピークと総称する.

$\mathrm{NbH}_{0.43}$ の共析変態に扣いては，Fig.4 の電気抵抗曲線 に示されるようにヒステリシスが認められる。内部摩擦浿 定扣よび示差熱分析に叔いても，この相変態でヒステリシ スが認められた。

相変態によらないピークが, $\mathrm{NbH}_{0.43}, \mathrm{NbH}_{0.75}$ 和よび

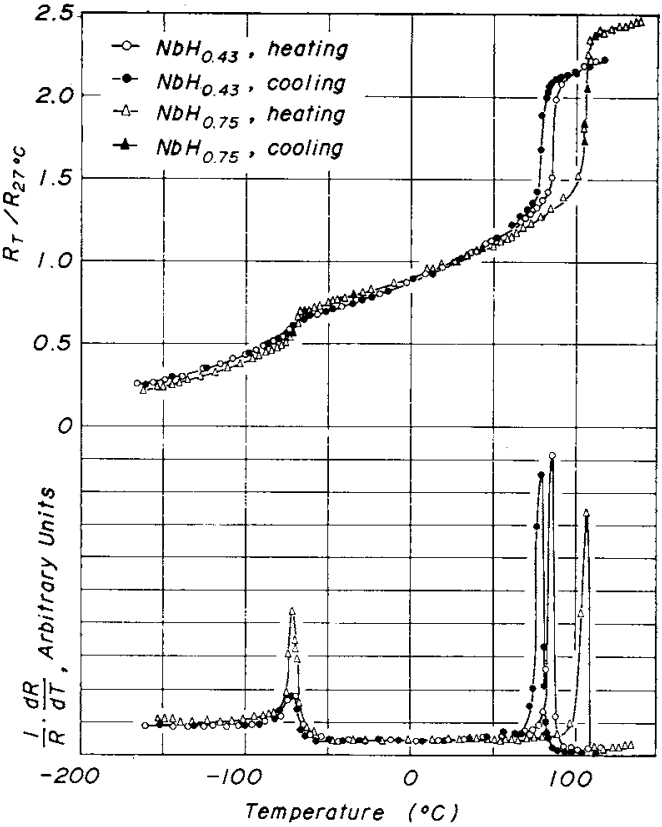

Fig.4 Resistance-temperature curves (upper) and their derivatives (lower) of $\mathrm{NbH}_{0.43}$ and $\mathrm{NbH}_{0.75}$. The resistances are relative to the resistance at $27^{\circ} \mathrm{C}$.

$\mathrm{NbH}_{0.84}$ においてそれぞれ -31 ，-35および $-117^{\circ} \mathrm{C} に$ 認められ，これらのピークの高盓側から共析変態蕰度ある いは $\beta-\alpha^{\prime}$ 変態温度に至る高い background damping がみ られる。これらの相変態によらないピークを本論文では低 温ピークと総称する.

各合金において認められた低温ピークは振動数依存性を 示した. 振動数を約 2 倍に変化させたとさの低温ピークの シフトの大きさから, $\mathrm{NbH}_{0.43}, \mathrm{NbH}_{0.75}$ 就よ゙ $\mathrm{NbH}_{0.84}$ に 牧けるそのピークの活性化エネルギーを求めてみると，そ れぞれ約 $30 \mathrm{kcal} / \mathrm{mol}, 35 \mathrm{kcal} / \mathrm{mol}$ 扎よび $25 \mathrm{kcal} / \mathrm{mol}$ で あった。

各合金において低温ピークの高温側にみられた高い background damping 恃大さな振幅依存性を示した。Fig. 5 は $\mathrm{NbH}_{0.75}$ に执いて振幅を 3 倍変化させた場合を示し

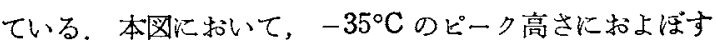
background damping の寄与は明らかではないが，このピ 一クの高さの変化は，室温近傍の background damping の 変化にほぼ等しい。

相変態によらないピークのらち, $\mathrm{NbH}_{0.43}$ におてて $165^{\circ} \mathrm{C}$ に，なた $\mathrm{NbH}_{0.75}$ 括よび $\mathrm{NbH}_{0.84}$ においては $135^{\circ} \mathrm{C}$ に認められたピークは，Fig.6のよらな振動数依存性を示 した。これらのピークの活性化ニネルギーは，因に示され ているよらに, $\mathrm{NbH}_{0.43}$ では $27 \mathrm{kcal} / \mathrm{mol}, \mathrm{NbH}_{0.75}$ では 25 $\mathrm{kcal} / \mathrm{mol}$ であった。これらのピークを本論文では高温ピー クと総称する。また $\mathrm{NbH}_{0.43}$ における高温ピークの高さは $200^{\circ} \mathrm{C}$ の時効により著しく低下した。 
$\mathrm{NbH}_{0.84}$ の薄莫を用いて, 低温の相変態および $\beta-\alpha^{\prime}$ 変態 にともなら組織変化を透過電子顕微鏡で観察した。

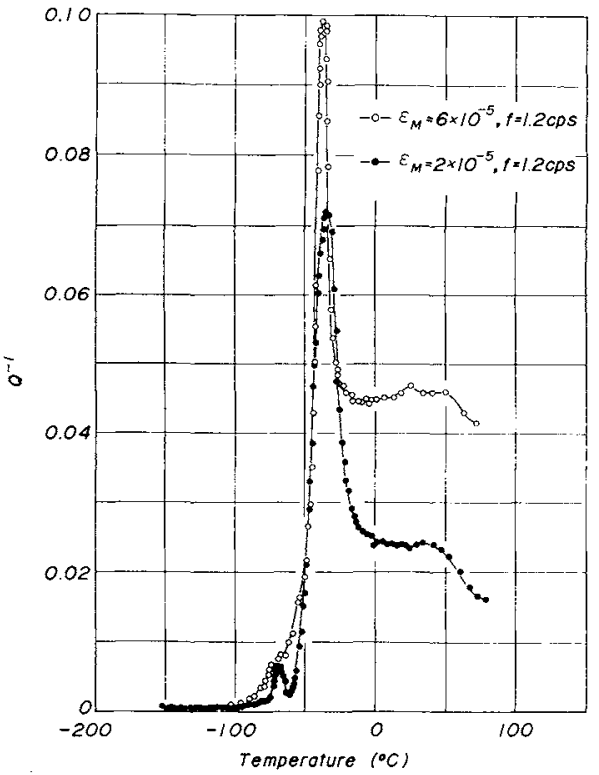

Fig.5 The amplitude dependence of the internal friction in $\mathrm{NbH}_{0.75}$.

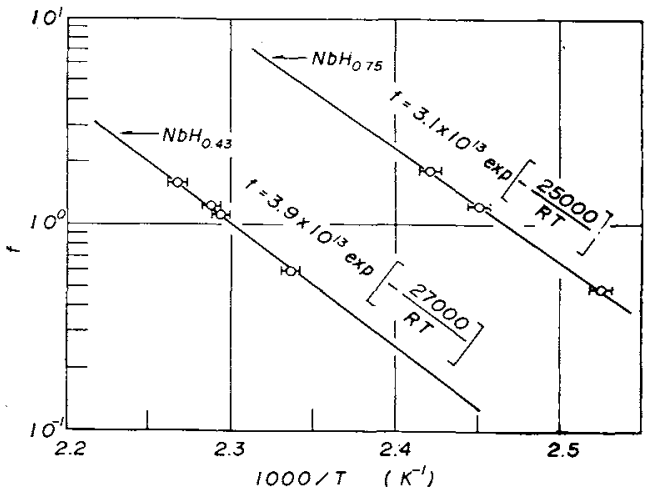

Fig.6 Arrhenius plots for the high temperature peak in $\mathrm{NbH}_{0.43}$.
Photo.1(a)は室温で観察された組織で，ドィイン境界 が誌められる. Photo.1(b)は Photo.1(a) と同一視野の暗 視野像であるが，写真をとる前に電子ビームを絞った際， ドメイン境界が移動した。矢印は同じ位置を示している。 Photo.1 (c)はPhoto.1 (a)に打いて, 点線で国まれた部分の 制限視野回折像と专の解析結果を示している。水素化物相 は侵入型規則構造をとるが(17)〜(19)，本覦文では，乙の電 子回折像の指数付忖に二オブ䅂子の指数付けを用いてい る. Photo.1(c)加ら明らかなよらに，基本格子反射の他 に，規則格子反射が認められる，規則格子反射は各ドメイ ソで変化した．Photo.1(c)にみられる規則格子反射は，矢 印を含んでいないドメインからの反射である，また基本格 子区射のはっきりした分裂は認められない. Photo.1(a)お よび(b)にみられる境界は，侵入型原子が規則配列したとき に観察される $\delta$ ーフリンジをもなったドメイン境界 ${ }^{(20)(21)}$ であることがわかる。すなわら，写真から明らかなよら に，フリンジは明視野像では左右非対称，腤視野像では左 右刘称になっている。またこのよらなドメイン境界は電子 ビームによって発生する熱応力により，容易に移動した。

これらのドメイン境界は $\beta-\alpha^{\prime}$ 变態温度 $\left(=112^{\circ} \mathrm{C}\right)$ 以上で は消失し，電子回折像において規則恪子㕅射もみられなく なった，冷却すると再びドメイン境界および規則格子反射 が観察された。 なた $\beta-\alpha^{\prime}$ 変態を繰返しても転位の発生は 認められなかった。

Photo.2 (a) は低温の相変態温度以下である $-150^{\circ} \mathrm{C} て ゙$ 観察された組織で，变態温度以上でみられると同様なドメ イン境界が認められる. Photo.2(b)住同一視野の暗視野 像である. Photo.2(c) は Photo.2(a) の点線で国まれてい る部分の制限視野回折像である. Photo.2(c) は二つのド メインを含も領域から得られた制限視野回折像であるが, Phato.1(c) と同じく基本格子のはっきりした分裂は認め られない，本た低温で観察される境界も，電子ビームによ る盓度上昇と，その結果発生する熱応才比より容㿽に移動 することが磼かめられた。

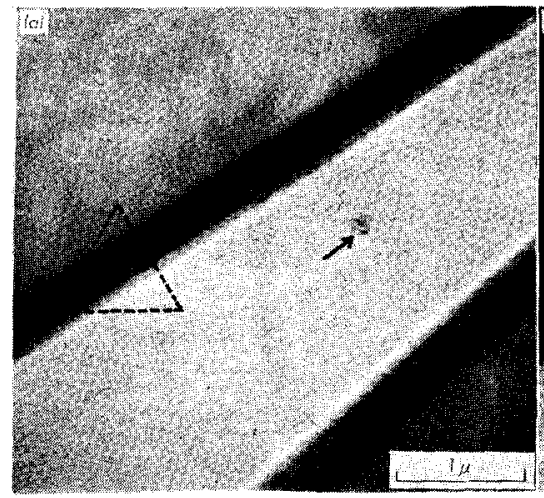

Photo.1 Domain boundaries in $\mathrm{NbH}_{0.84}$ at room temperature. image, (c) diffraction pattern obtained from the area denoted in (a)

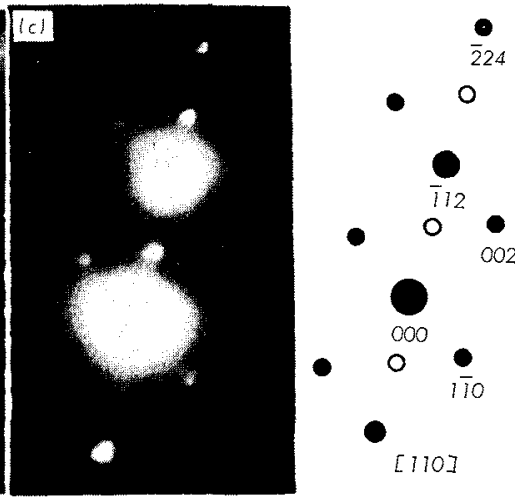

(a) bright-field image, (b) dark-field 


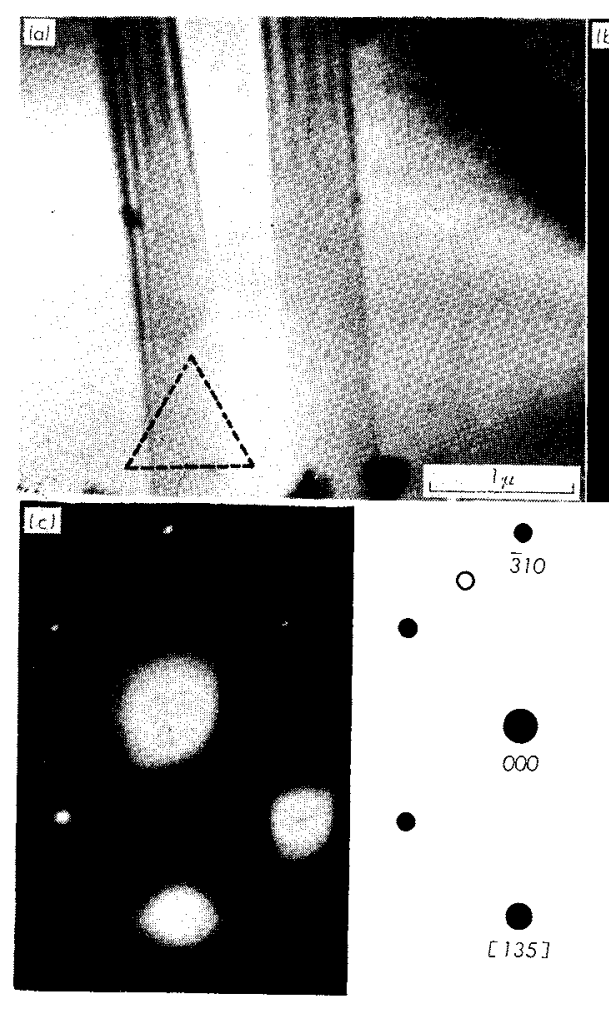

IV. 考察

$\mathrm{NbH}_{0.43}, \mathrm{NbH}_{0.75}$ および $\mathrm{NbH}_{0.84}$ の内部摩擦浿定におい て珰められた相変熊高温ピーク，相変態低湓ピーク，低温 ピークとその高温側にみられる background damping およ び高酯ピークについて考察する。

\section{1. 相変態ピーク}

相変態に基つくく内部摩擦の理諭的解釈は多くの研究者に よって試みられているが不明の点が多い，本節では内部摩 擦と相変態との対応扎よび相变態にとむなら水素化物中の 水素の規則配列の変化などについてのべる.

\section{(1) 相変態高温ピーク}

$\mathrm{NbH}_{0.43}$ に和いては共析変態㳑度に, $\mathrm{NbH}_{0.75}$ および $\mathrm{NbH}_{0.84}$ に括いては $\beta-\alpha^{\prime}$ 変態盓度に相変態高盜ピークが 認められた，共析変態にともならピークはWert ら ${ }^{(9)}$ 亿 よってすで報告されており， $\beta$ - $\alpha^{\prime}$ 変態にともならピーク は著者ら (11)によって報告されている。

共析变態においてい，Fig.3に示されるようにヒステり シスが贸められたが，この現象は Walter と Chandler ${ }^{(2)} に$ よりすで報告されている。またこのようなとステリシス は $\alpha-(\alpha+\beta)$ 变態に拈いても見出されて㧍り ${ }^{(10)}$ ，いずれの 場合火扎いてを，母相より約 $10 \%$ 密度の小さい水素化物 相が析出あるいは再固溶する際の目相あるい性出相の塑 性変形によるものと考元られている(22). $\mathrm{NbH}_{0.43}$ において は上述の塑性変形によって生成したと考えられる高密度の 転位が観察された (23)。
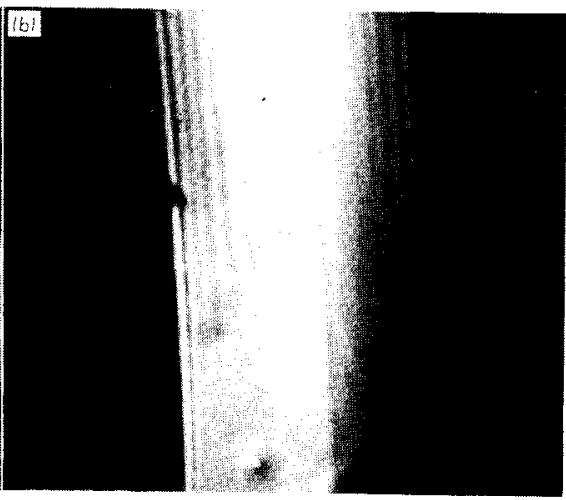

$\overline{2} \overline{1}$ Photo.2 Domain boundaries in $\mathrm{NbH}_{0.84}$ at $-150^{\circ} \mathrm{C}$.

(a) bright-field image,

(b) dark-field image,

(c) diffraction pattern obtained from the area denoted in (a)

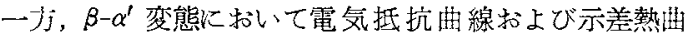
線が急激に変化する温度範囲は，Fig.3 および Fig.4 に示 されているよ に $10^{\circ} \mathrm{C}$ 以内であり，これに対応した内部 摩擦のピークの幅も狭い， $\beta \rightarrow r \alpha^{\prime}$ 変態は $\beta \rightarrow \alpha^{\prime}+\beta \rightarrow \alpha^{\prime}$ の過 程を経るが，内部摩擦のピーク温度がこの過程のいずれに 対応するのか明らかではない。昰た $\beta-\alpha^{t}$ 变態において はヒステりシスは諗められなかった．本変態には前述の共 析変態に拉けるような大きな体積変化をともなわないため と考光られ，本変態夌繰り返した $\mathrm{NbH}_{0.84}$ 中には転位の発 生が珰められなかった。

(2) 相変態低温ピーク

$\mathrm{NbH}_{0.43}$ 物よび $\mathrm{NbH}_{0.75}$ においては $-70^{\circ} \mathrm{C}$ に, $\mathrm{NbH}_{0.84}$ においては $-38^{\circ} \mathrm{C} に$ 相変態低洫ピークが㤎められた。低 温の相変態は $\beta$ 相中の水素空孔の配列の変化をともならる ので，中性子回折(18)(19)，X線回折 ${ }^{(24)}$ 小よび電子回折 $^{(25)}$ によって報告されている，報告されている変態温度は，こ れらの実験に使用された試料の水素濃度が互いに異なるこ 之，あるいはNb-D 合金が用いられている(18)(19)ために 必ずしも一致していない，本研究では， $\beta$ 相中の水素量が 増大するにつれて，低温の相変態滥度が高くなることを見 出した, $\mathrm{NbH}_{0.43}$ と $\mathrm{NbH}_{0.75}$ とでその変態温度がほとん ど変らないのは，Fig.1 の状態図から明らかなるらに， $\mathrm{NbH}_{0.43}$ において $\alpha$ 相と共存している $\beta$ 相の組成が空温以 下で $\mathrm{NbH}_{0.75}$ にはぼ等しいためだと考它られる。

$\beta$ 相は斜方晶である(2)(17)(24)(26)(27).Fig.7(a)に $\beta$ 相の 構造とニオブ格子との関係を示している．Fig.7(b)には重 


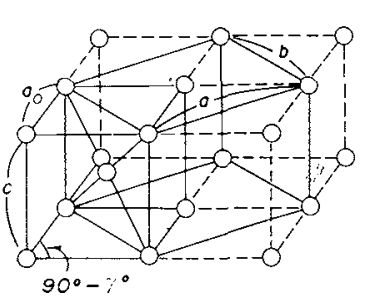

(o)

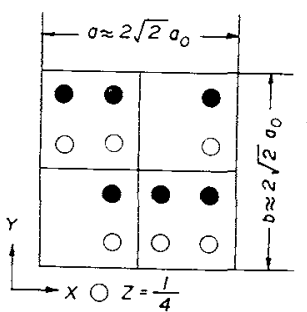

- $\frac{3}{4}$

(c)

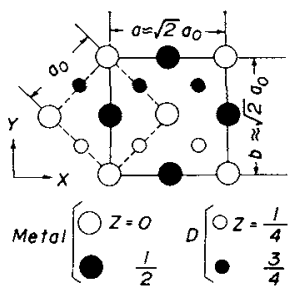

(b)

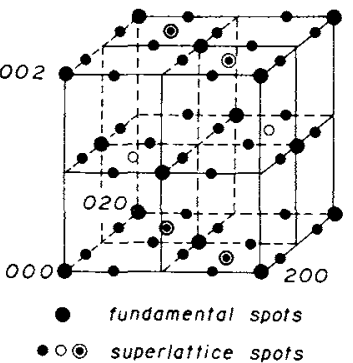

(a)
Fig.7 (a) Structure of niobium hydride in relation to that of niobium. (from Wainwright et al. ${ }^{(27)}$ )

(b) Proiection of ordered $\mathrm{NbD}$ structure onto the (001) plane. Broken lines denote the unit cell of $b c c$ metal lattice. (from Somenkov et al. ${ }^{(18)}$ )

(c) $\mathrm{NbD}_{0.75}$ superstructure (from Somenkov ${ }^{(19)}$ )

(d) Reciprocal lattice of $\mathrm{NbH}_{0.75}$. Open circles are the superlattice reflections after the first transition (ordering according to $\mathrm{NbD}$ type), and the others occur after the second transition (ordering according to $\mathrm{NbD}_{0.75}$ type) (18) Concentric circles were observed besides open circles after the first transition. (present work)

水素化物 $\mathrm{NbD}$ の重水素の位置(17) 示しており，重水素は ニォブ格子中の四面体位置に規則配列している，NbHに おける水素の配列も NbD のそれと同じであららと考古ら れている。

$\mathrm{NbH}$ の組成より水素が少ない場合には，水素の空孔が 存在し, Somenkov ら ${ }^{(18)}$ はする温度以下になると水素の空 孔が規則配列するよらになると報告している，Fig.7(c)虫 Somenkov ${ }^{(19)}$ が中性子回折で決定した重水素化物の低温で の规則構造，すなわち Fig.7 (b)の规則構造を基礎とした $\mathrm{NbD}_{0.75}\left(=\mathrm{Nb}_{4} \mathrm{D}_{3}\right)$ 規則構造を示している. Fig.7 (d)はその

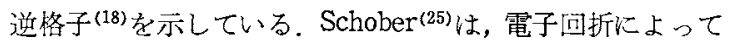
水素化物の場合も同じ逆格子が得られることを確かめてい る. 図中の白丸は低温の相変態温度以上の $\beta$ 相においても みられる規則格子反射であると報告されている(18)(21)。

Photo. 3 は, 低温の相変態温度から $\beta-\alpha^{\prime}$ 変態温度の範困 に执いて観察さ机る電子回折像の一例で，Fig.7 (d) に示 される白丸の他に，同心円の䙺則格子反射も認められる。 Schober ${ }^{(25)}$ は， $\beta$ 相が $\mathrm{NbH}_{0.75}$ 規則構造を示す相湾態す る前に，まずこのような規則格子反射省示寸相になると報
告している。しかしながら，本研究に执いてこのうら な規則格子反射は $\beta$ 相において得られた。 また示差熱分析 特よび電気抵抗測定に和いても，Schober ${ }^{(25)}$ が報告してい るような2段階の変態は諗められなかった。

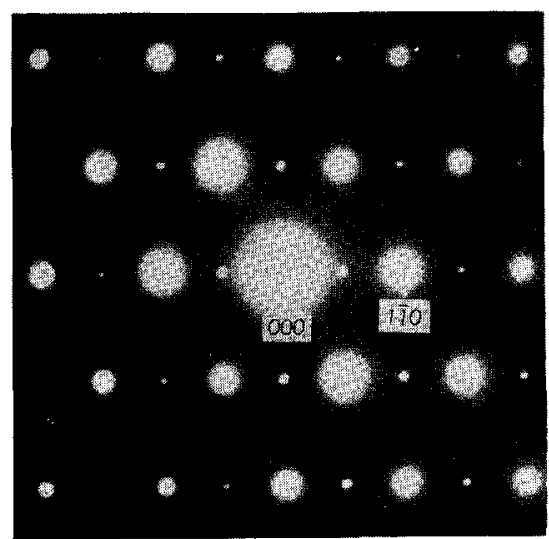

Photo.3 Diffraction pattern in $\mathrm{NbH}_{0.84}$ at room temperature. The electron beam was parallel to a [111] direction.

\section{2. 相変態に基づかないピーク}

（1）低温ピークとその高温側にみられる background damping

$\mathrm{NbH}_{0.43}, \mathrm{NbH}_{0.75}$ および $\mathrm{NbH}_{0.84}$ に拉いてそれぞれ -31，-35尔よび $-117^{\circ} \mathrm{C}$ に緩和型のピークが楒められ， これらのピークから共析変態温度あるいは $\beta-\alpha^{\prime}$ 変態温度 に至る高い background damping がみられた。この background damping 忙 Fig.5 に示されるよらに著しい振幅依 存性を示した。

水菜化物相 $(\beta$ 相和よびそれが低淇で相変態した相) 中に は, Photo.1および Photo.2 とみら礼るよらなるーフリン ジを示すドメイン境界がしばしば観察され，Schoberら ${ }^{(21)}$ の観察結果之一致した。A Amelinckx ら (20)(28)(29)の詳細な 研究によると， $\delta$-フリンジを示すドメイン境界は非常に小 さな双㽞べクトルをと㫗なった整合双晶境界であると報告 されている。 $\delta$ ーフリンジを示すドメイン境界は，電子線に より発生する熱応うで容易に移動するのがしばしば観察さ れた。 Photo.1にはその一例を示している。このことか ら，この上らなドメイン境界は，外部応批よっても容场 に移動すると思われる。

水素化物相中の水素は，二オブ格子中の四面体位置に Fig.7 (b) 要たは (c) に示されるよらに規則配列し(17)〜(19)， 二オブ格子を斜方晶に歪ませる．水素化物根中心は多数の ドメインが存在し，水素の睍則配列の方向は隣り合ったド メインで異なっている，したがって，一軸方向の外部応力 が水素化物に加えられた場合，ドメイン内の水菜の再配列 をともなら枕力の緩和機構が考えられる。また各ドメイン 内で規則配列している水素間には相互作用が生じていると

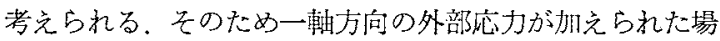


合, 各水素原子はSnoek 効果の上らな単独の動きが困難 であり，協力的な動きをとらねばならないであろう。 また 再配列のための水素の協力的な動きは，ドメイン境界近傍 において比較的容易に起こると考兵られる。

Fig.8は，上述の機棈て上って外部灾力を緩和する间能 性のある $\mathrm{NbH}$ 中の 2 種類のドメイン境界と，それらの移 動硙をなら水素原子の動きを示している. 図中の実線で 囲玉れた一つの長方形は，Fig.7(b) と同じく， NbH の単 位胞を(001)面に投影したものであるが，歪量を誝掁して 示している. 白机と黑丸は水素原子を，点線はドメイン境 界を示している，図から明らかな上らに単位胞は，水素が 密に並んでいる方向に大きく歪んでいる。

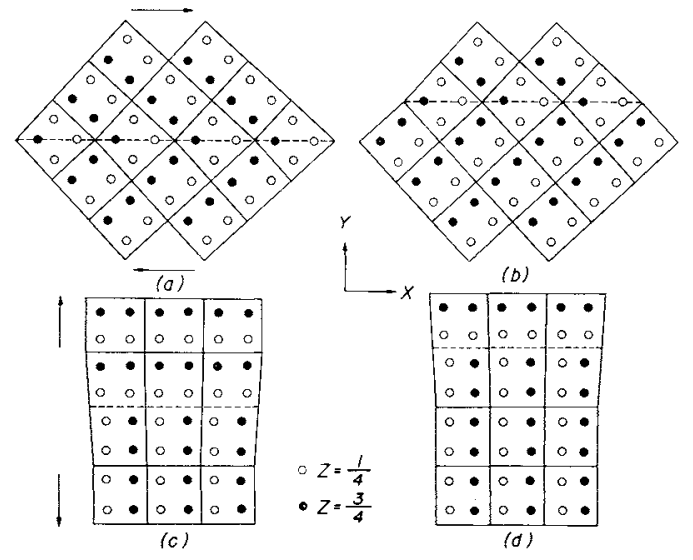

Fig.8 Schematic representation of two kinds of domain boundaries in $\mathrm{NbH}$. It shows that movements of domain boundaries ( $(\mathrm{a}) \rightarrow$ (b) or $(c) \rightarrow(d))$ are accompanied by movements of hydrogen atoms.

Fig.8(a)および(b)に示されているY軸に垂直なドメイ ン境界は整合双晶境界になっている。いま（a）に秃いて， Y軸传直な面に矢印の方向にせ九断応力が加党られた場 合を考觉る。この外部応力を緩和するには，境界がY軸の 正の方向に移動していけばよい，境界は水紮原子が位置を 変えることにより移動する，たとえば Fig.8(a) に示され るドメイン境界が(b)に示される位置に移動するには，(a) に示される境界上り上方のドメインに执いて，境界々最近 接の位置にある水素原子で，Z朝関する位置が $1 / 4$ にあ るもの(白丸)が 3/4(黒丸)に，3/4にあるものが $1 / 4$ に移動す ればよい，次に，Fig.8(c)には，Y軸方向に張力が加党ら れたときにそるを緩和できると考えられるドメイン境界を 示している，張力を緩和するには，境界が軸の正の方向 に移動すればよい，境界が(c)に示される位置から(d)に示 される位置に移動するためには，図から明らかなように。 境界上り上の各単位胞中の 2 個の水素原子が Z軸関する 位置を同時湾えればよい。

上述のようにドメイン境界は水素原子の再配列によって 移動する，境界が移動する際，境界全体が同時化移動する
よりは，境界の一部がまず移動した後に，その領域が桩 がっていく機構のほうがより低いエネルギーで起こるであ らう，すなわら転位が移動する際のキンク対の機構 ${ }^{(30)}$ ， あるいは双晶境界が移動する際の円板状の領域が抎がって いく機構 (31)等と同様な機構が考古られる. 水素化物中の ドメイン境界において，最初に境界の一部分が移動するた

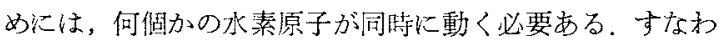
ち水素原子の同期的な動きが必要になる。

ドメイン境界の移動炕おいて，境界の一部の领域が移動 することが律速段階になっていれば，外力によるそのよう な領域の形成は綏和型の内部摩擦を生じるであろら。また 境界の一部の移動々その領域の拡がりが容易になり，境界 が外力に対して不可逆的に移動するようになれば，とステ リシス型の内部摩擦が生じると考えられる。本研究で珰め られた相変態基づかない緩和型の低温ピークおよびその 高温側にみられたヒステリシス型の background damping はこのような機構によるものと考えられる。

Photo.1 および Photo. 2 にみられるような $\delta$ みリンジ を示すドメイン境界は，前述したように，小さい双晶ベク トルをるった整合双晶境界であると報告されている(20)(28) (29). また観察された境界の晶癖面はニオブ格子の $\{100\}$ 面 に平行なものが多かった。これらの境界は Fig.8 と示され た双晶に相当すると考劣られる。この双晶のせん断変形量 は $a / b$ (Fig.7 参照)によって決悉る， $a / b$ は水素化物の水 素濃度によって変化する(24)(27). Wainwright ら ${ }^{(27)}$ の室温 でのX線回折結果から，本研究で用いた試料のらち $\beta$ 単相 のものの $a / b$ を求めてみると, $\mathrm{NbH}_{0.75}$ では $1.009, \mathrm{NbH}_{0.84}$ では 1.013 となる。, $\mathrm{NbH}_{0.75}$ 打よび $\mathrm{NbH}_{0.84}$ 中に, Fig.8 に示されていると同様の双晶ができたとして，それらの双 晶のせん断変形量を概算してみると，それぞれ0.018およ び 0.026 となる。これらの数值から双晶境界が同一距離だ 忊動く場合の応力緩和量は, 水素濃度が高いほど大きくな ることがかかる。したがって，双晶境界の䔟動によって起 こる background damping の大ささと双晶のせん断変形量 との間には密接な関係があると考えられる，Fig.2 から明 らかなよらに $\mathrm{NbH}_{0.84}$ の background dampingは $\mathrm{NbH}_{0.75}$ に比べて著しく大きい。

振動数依存性から求めた低温ピークの活性化エネルギー は， $\mathrm{NbH}_{0.43}, \mathrm{NbH}_{0.75}$ および $\mathrm{NbH}_{0.84}$ において，それどれ 約 $30 \mathrm{kcal} / \mathrm{mol}, 35 \mathrm{kcal} / \mathrm{mol}$ 抽よ゙ $25 \mathrm{kcal} / \mathrm{mol}$ である. これらの值は， $\beta$ 単相領域でのNMR の測定 ${ }^{(32)(33)}$ から得 られている水素の昖散の活性化ェネルギー約 $5 \mathrm{kcal} / \mathrm{mol}$ 亿 比較して著しく大きい，このことは低温ピークが単独の水 素の動きによるものではなく，水素の協力現象をともなう ことを示唆している。

低温ピークの半溉幅は、そのピーク高さへの background damping の寄与が明らかでないので, 正確な值が求められ ない。しかし，Fig.2の低温ピークの形状から概算された 
$\mathrm{NbH}_{0.43}$ および $\mathrm{NbH}_{0.75}$ のピークの半価幅は，それぞれの ピークが単一の Debye ピークと作定して, その活性化工 ネルギーから求められた半価幅とほぼ一致している。一 方, $\mathrm{NbH}_{0.84}$ の低盕ピークの半価幅は, 単一の Debye ピー クのとれよりも約 6 倍大さい。

緩和型ピークの活性化エネルギーと測定振動数との間に は次式が成立する。

$$
f=f_{0} \exp (-\Delta H / R T)
$$

ここに $f$ は測定振動数, $f_{0}$ は振動数項, $\Delta H$ は活性化云齐 ルギー，Rはガス定数，Tはピーク温度である、振動数依 存性から求められた活性化エネルギーとピーク温度から $f_{0}$ の值を, $\mathrm{NbH}_{0.43}, \mathrm{NbH}_{0.75}$ および $\mathrm{NbH}_{0.84}$ の低温ピークに ついて求めてみるととれぞれ約 $10^{27} \mathrm{sec}^{-1}, 10^{30} \mathrm{sec}^{-1}$ およ び $10^{35} \mathrm{sec}^{-1}$ となる。いままてた見出されている種々の緩 和現象の $f_{0}$ は，Wertと Marx ${ }^{(34)}$ とよれば $10^{13} \mathrm{sec}^{-1}$ ， ま た Batist(35) によれば 1011〜1016 $\mathrm{sec}^{-1}$ と報告されている。 低温ピークの $f_{0}$ はそれに比へて異状に大さい。この点に 関しては，今後さらに检討する必要があると思われる。

\section{(2) 高温ピーク}

$\mathrm{NbH}_{0.43}$ においては $160^{\circ} \mathrm{C}$ に， $\mathrm{NbH}_{0.75}$ および $\mathrm{NbH}_{0.84}$ に占いては $135^{\circ} \mathrm{C}$ に琶められた高温ピークの活珄化エネ ルギーは，二オブ中の酸素の拡散の活性化エネルギー， $26.6 \mathrm{kcal} / \mathrm{mol}^{(16)}$ ，とほ隹等しい，また高密度の転位が存 在する $\mathrm{NbH}_{0.43}{ }^{(23)}$ の高温ピークの高さは $200^{\circ} \mathrm{C}$ での封効 により著しく低下した。したがって，高温ピークはそれぞ れの合金中の酸素のS Snoek 效果によるものと考方られる。 $\mathrm{NbH}_{0.75}$ および $\mathrm{NbH}_{0.84}$ における高温ピーク温度は，二才 ブの Snoek ピーク温度に比較して低温に移っており，そ の活性化エネルギーもかずかに低い。これは主にニオブ 格子が水素原子により約 $3 \%$ (27) 伸されているためと考 えられる。应た，低濃度水素合金の場合には水素と酸素之 の相互作用は非常に小さいことが報告されているが(36)， $\mathrm{NbH}_{0.75}$ および $\mathrm{NbH}_{0.84}$ のような高濃度水索合金の場合， 酸素の近傍には水素が常に存在する状態なので，酸素の Snoek ピーク温度のよらな高温においても，無視できない 相互作用が生じている可能性がある。

\section{V. 総 括}

$\mathrm{NbH}_{0.43}, \mathrm{NbH}_{0.75}$ および $\mathrm{NbH}_{0.84}$ の内部摩擦を $-170^{\circ} \mathrm{C}$ から $220^{\circ} \mathrm{C}$ の盓度範囲で測定した。観测された内部摩擦の ピークを示差熱分析，電気抵抗測定，透過電顕観察および 電子回折の結果と比較検討した。

各合金において相変態执よび不純物酸素に基つく内部摩 擦のピークが讃められた。てて他に相变態によらない低温 ピークと，そのピークから共析変態温度または $\beta-\alpha^{\prime}$ 変態 温度に至る温度範用で高い background damping を見出 した。これらの相変態によらない内部摩擦が水菜化物中の ドメイン璄界に関連したものであることを，透過電顕観察
結果炕基ついて提案した。すなわち，低温ピークはドメイ ン境界での水素の協力的な動きによる緩和型の内部摩擦で あり， background dampingはドメイン境界の非可逆的な 移動をともなったヒステリシス型の内部摩擦であると結論 Lた.

終りに貴重な討諭と助言をして下さった京都大学工学部 高村仁一教授に感謝いたします。また終始御鞭撻して下さ った当研究部の木村啓造搏士および討論のみならず電気抵 抗测定に協力して下さった当研究室の松本武彦氏に感謝い たします。

\section{文献}

(1) W.M.Albrecht, W.D.Goode and M.W.Mallet: J.Electrochem.Soc, $106(1959), 981$.

(2) R.J.Walter and W.T.Chandler : Trans.Met.Soc. AIME, $233(1965), 762$.

(3) G.Cannelli and L. Verdini : Ric.Sci., 35(1966), 98.

(4) G.Schaumann, J.Völk1 and G.Alefeld : Phys. Rev.Letters, 21 (1968), 891.

(5) G.Schaumann, J.Völk1 and G.Alefeld : Phys. Status Solidi, $42(1970), 401$.

(6) R.H.Chambers and J.Schultz : Acta Met., 8 $(1960), 585$.

(7) L.J.Bruner : Phys.Rev., 118 (1960), 399.

(8) P.B.Bordoni, M.Nuovo and L.Verdini : Phys. Rev., 123(1961), 1204.

(9) C.A.Wert, D.O.Thompson and O.Buck: J.Phys. Chem. Solids, $31(1970), 1793$.

(10) O.Buck, D. O.Thompson and C.A.Wert : J.Phys. Chem.Solids, 32 (1971), 2331.

(11) M.Amano, T.Matsumoto and Y.Sasaki : Scripta Met., $7(1973), 371$.

(12) P.Kofstad and R.A.Butera : J.Appl. Phys., 33 (1963) , 1517.

(13) R.A.Butera and P.Kofstad : J.Appl. Phys., 34 (1963), 2172.

(14) W.E.Wallace : J.Chem.Phys., 35(1961), 2156.

(15) W.S.Saba, W.E. Wallace, H.Sandmo and R.S. Craig, J. : J. Chem. Phys., 35(1961), 2148.

(16) R.W.Powers and M.V.Doyle : J.Appl. Phys., 30 (1959), 514.

(17) V.A.Somenkov, A.V.Gurskaya, M.G.Zemlyanov, M.E.Kost, N.A.Chernoplekov and A.A.Chertkov : Sov.Phys. -Solid State, 10(1968), 1076.

(18) V.A.Somenkov, V.F.Petrunin, S.Sh. Shil'stein and A.A.Chertkov : Sov.Phys.-Crystallogr., 14 (1970), 522 .

(19) V.A.Somenkov : Ber. Bunsenges. Physik. Chem. $76(1972), 733$.

(20) I.van Landuyt, R.Gevers and S.Amelinckx : Phys.Status Solidi, 13(1966), 467.

(21) T.Schober, M.A.Pick and H. Wenzl: Phys. Status Solidi (a) , 18(1973), 175.

(22) D.G. Westlake : Trans. Met. Soc. AIME, 245 (1969), 287.

(23) M.Amano and Y.Sasaki : Phys.Status Solidi (a), $19(1973), 405$.

(24) M.A.Pick : Jü1-Conf-6(vol.1), (1972), 90.

(25) T.Schober : Scripta Met., 7(1973), 1119. 
(26) G.Brauer and R.Hermann : Z.anorg.allg. Chem., $274(1953), 11$.

(27) C. Wainwright, A.J.Cook and B.E.Hopkins : J. Less-Common Metals, 6(1964), 362 .

(28) R. Gevers, P. Delavignette, H. Blank, J. van Landuyt and S.Amelinckx : Phys.Status Solidi, $4(1964), 383$.

(29) S.Amelinckx : Surface Sci., 31 (1972), 296.

(30) A.Seeger: Phil. Mag., 1(1956), 651.

(31) K.Sumino : Acta Met., 14(1966), 1607.
(32) D.Zamir and R.M. Cotts: Phys. Rev., 143A (1964), 666.

(33) B.Staliński and O.J.Żogal : Bull. Acad. Polon. Sci.Sér.Sci.Chim., 13(1965) , 397.

(34) C.Wert and J.Marx : Acta Met., 1 (1953), 113.

(35) R.De Batist : Internal Friction of Structual Defects in Crystalline Solids, Noth-Holland Pub. Com., Inc-New York, (1972), 74.

(36) C.Baker and H.K.Birnbaum: Acta Met., 21 (1973) , 865.

\section{銅単結晶の圧延における変形挙動と圧延集合組織}

\section{吉岡正三* 目良光男* 森井賢二**}

Shozo Yoshioka, Mitsuo Mera and Kenji Morii : Deformation Behavior of Single Crystals of Copper during Rolling and Rolling Texture. The orientation dependence of the deformation behavior of single crystals of copper during rolling deformation has been investigated by rolling 80 crystals, each having a different initial orientation. The rolling textures of an imaginary polycrystal in which the effects of the constraints of each grain from grain boundaries and neighboring grains during deformation may be ignored ("pseudopolycrystal") were derived from the orientations attained by rolling of numbers of single crystals.

The inhomogeneities of deformation and the courses of the orientation changes in the copper single crystals were surveyed by means of optical microscopy and reflection electron diffraction technique, respectively. The deformation behavior of the rolled crystals having initially the rolling plane normals in the stereographic triangle 100-101-111 could be grouped into the following three types, depending upon the rolling direction : (1) Inhomogeneous deformation, mainly arising on the crystals having the rolling directions in the vicinity of the [203]-[112] orientations in a stereographic projection, (2) Abnormal lattice-rotation, found around the rolling direction in the crystals having the rolling direction near the [111] orientation, (3) Homogeneous deformation, observed in the crystals with the orientations other than given above. These deformation behaviors were roughly explained in terms of the orientation dependence of the kinds and the characters of the active slip systems in single crystals during rolling.

The rolling textures of the "pseudo-polycrystal" at the reductions of 50 and $96 \%$ agreed, respectively, with the intermediate type- and pure metal type-textures which should develop in the polycrystalline copper rolled up to the corrsponding reductions. It is concluded from this fact that the contributions of grain boundaries and neighboring grains to the texture development in polycrystalline copper are not so pronounced as to alter the ideal orientations of the rolling texture.

(Received May 27, 1974)

\section{1. 緒言}

$f c c$ 金属多結晶には, $50 \%$ 程度の比較的低圧延率におい て中間段階の圧延集合組織が形成され，さらに約 $90 \%$ 以 上の高圧延率に打いて純金属型圧延集合組織が形成される ことが知られている(1)(2).また,このような集合組織の発達 過程に関して，すでに二，三の研究がなされている(3)〜(6). しかし、これらの研究炕叔てては，多結晶中の各結晶粒の 变形行対して，一定ひずみの拘束条件，西るい性一すべ り变形が仮定されており，次のような結晶の変形挙動につ いては注とんど考慮されることがなかった。
平面ひずみの条件下で拘束圧延されたアルミニウム単結 晶には，すべり帯の観察に上れば，芷延初期方位に依存し て, 变形の不均一性(变形帯)が忍められること, 叔よび Taylor 解析より予想されるにかかわらず活動が諗められ ないすべり系が存在することが，池咕ら六〜(9)によって示 された。また，著者ら ${ }^{(10)} は ，$ 平面ひずる变形を仮定した Taylor 解析上り予想さ礼る安定方位 $\{4411\}<11118>^{(4)}$

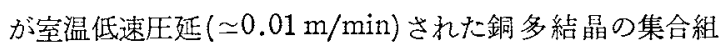
織中に認められないことを, 反射電子回折法炕よって確認 した.

これらの観察結果は， $f c c$ 金属多結晶の圧延集合組織の

* 大阪府立大学工学部 (College of Engineering, University of Osaka Prefecture, Sakai)

** 大阪府立大学大学院 (Graduate School, University of Osaka Prefecture, Sakai) 